\title{
UN-BELONGING AND DEATH VANISHED \\ BY STORYTELLING: ISHIGURO'S KATHY H. AS A DYSTOPIAN SCHEHERAZADE
}

\author{
Manuel Botero Camacho \& Miguel Rodríguez Pérez \\ Universidad Complutense de Madrid
}

\begin{abstract}
Throughout this article the figure of Kathy H., protagonist of Kazuo Ishiguro's Never Let $M e G o$, is going to be presented as a replication of Scheherazade, adapting the trope of the storyteller to her dystopian and postcolonial context in a narration that explores the diverse roles of narratives in our lives. They serve to create a sense of individual and communal identity; constructing and shaping our past, our dreams and hopes; enabling us to recover all that we have lost and, especially, to communicate our experiences and survive in the memories of others.
\end{abstract}

KeYwords: Gendered Myth, Ishiguro, Scheherezade, Storytelling, Un-belonging.

\section{RESUMEN}

A través de este artículo la figura de Kathy H., protagonista de Never Let Me Go de Kazuo Ishiguro, será presentada como una réplica de Sherezade, adaptando la idea del cuentacuentos a su contexto poscolonial y distópico en una narración que explora las diversas funciones de nuestras narrativas cotidianas. Estas sirven para crear un sentido de identidad individual y colectiva, construyendo y modelando nuestro pasado, nuestros sueños y esperanzas; permitiéndonos recuperar todo lo perdido y, especialmente, comunicar nuestras experiencias y sobrevivir en la memoria de otros.

Palabras Clave: Ishiguro, Sherezade, Narrativas, Desarraigo, Mito de género.

DOI: https://doi.org/10.25145/j.recaesin.2018.76.17

Revista Canaria de Estudios Ingleses, 76; April 2018, pp. 243-253; ISSN: e-2530-8335 


\section{INTRODUCTION}

The One Thousand and One Nights constitutes a literary construction that incorporates and synthesizes the myriad of myths, legends, creeds, literary works and folktales that belong to the different regions of the Middle East, North Africa and South Asia - some transmitted in the oral tradition while others translated and collected afterwards ${ }^{1}$ - from prehistoric times up to the sixteenth century (Khan 2012: 38), blending fantasy and history into a common mythological domain. ${ }^{2}$ Although in Arabic literature traditionally the Nights have not enjoyed the favour of academics or intellectuals (Irwin 1994: 4), their influence on Western literature has been monumental (Khan 2012: 39; Irwin 1994: 237, 290-91). This has not been merely on terms of narrative form and content but by shaping the Western collective image of the East, as the fantasy of a mysterious and exotic land, up until our current context of a postcolonial and globalised world. This image constitutes a "purely imaginative geography,." as Coleman affirms using Edward Said's term, through which "the West seeks to expel or disavow." all the stereotyped values associated to the East (2005: 247). Such construct has also enabled Western authors to find a location from which to criticise Western society (Coleman 2005: 247). In that sense the East has been turned into a faery land, a place whose reality is that of the myth, becoming a source for comfort and of romantic longing when compared to the mundane character of everyday life.

Scheherazade, protagonist of the Nights' main narrative thread, incarnates the learned heroine who has become in the minds of the audience a proto-feminist figure (Blythe 2015) that overcomes the objectification that transforms women into expendable possessions. Scheherazade, as a cultivated woman, attains her status by rising above the stereotyped image of women when she decides to put an end to the slaughter suffered by the sultan's mistresses with her own sacrifice, prevailing over this oppression in the end thanks to the strategy of telling stories to survive. In addition to her own example, her tales offer a varied depiction of women and gendered roles that, though entrenched in the vision of patriarchy, at least gave them the agency that female characters from other narratives lacked (Blythe 2015).

Narration as a strategy to enchant, survive or save others finds its analogy in some of the first tales ${ }^{3}$ as in the "Story of the Trader and the Jinni." a connection also highlighted by Ferial J. Ghazoul (1996: 84), in which each of the three shaykhs

${ }^{1}$ According to Irwin, the stories were translated from Persian and Hindi in the early eight century, forming “The Thousand Nights." (1994: 48). Although Khan defends the element of oral transmission, Irwin sheds some doubts on this, claiming that such assumption is only partially true (1994: 103, 113).

${ }^{2}$ Mythical character understood in the sense described by contemporary anthropologists and historians. (Mair 1963, Leach 1970: 58 qtd. Moblo 1997: 696; Eliade 1968: 1-2).

3 This unified thematic has also been identified by Irwin concerning Mahdi's thesis about the common origin of the first 280 nights that eventually composed the core of Galland's translation. (Irwin 1994: 56). 
that the merchant encounters narrates a story to the Jinni so that he would spare the merchant's life (Nights 1: 24-37). Similarly, the tales of the three Kalandars are narrated to escape death at the hands of the Three Ladies of Baghdad (Nights 1: 82185) - an inversion of the main narrative frame's gender design. Simultaneously, each of the old men's narrations and the Kalandars' tales serve Scheherazade to deter her execution for one day more. Narration as a form surmounting difficulties is inherent to human beings; it facilitates our understanding of reality, and as such, it has served survivors of situations of systematic oppression to survive and, especially, to overcome traumatic experiences (Jacobi 4-7). Examples of this process are at the core of the literature (both fictional and biographical) of ethnic minorities, of marginalised individuals, the accounts of a group's diaspora and, of course, in the literature of the holocaust. In women's writing this mechanism is also used a part of the strategies to break the silence. These forms of narratives, regardless of being factual or fictional, represent a medium through which some of the author's -or narrator's- inner demons can find an outlet in a fictional form that facilitates expression by avoiding the direct confrontation of the traumatic experience thanks to metaphoric imagery and language.

\section{THE DYSTOPIAN SCHEHEREZADE}

Even though Scheherazade could very well be analysed through the aforementioned perspective as part of an oppressed group, the figure and archetype she has become to represent in the literature of diasporic communities, like the ArabAmerican (Braga and Gonçalves 81), makes her more suited to be read as a precursor of numerous characters developed in the context of postcolonial and contemporary literature, where she can be explored in her mythical dimension and where the themes of identity and belonging can be fully articulated. Even though Scheherazade was a member of the sultan's court and is helped by her sister Dunyazad (Nights 1: 23-24), her un-belonging stems from the alienation suffered by an individual waiting for death, condition that separates her, even from those close to her; just as the dying characters in Ishiguro's novel will feel separated from their carers' reality (Ishiguro 276). As a result, storytelling does not only offer both Scheherazade and Kathy the means to survive, but to be reunited with their loved ones in the sharing of tales that are part of the cultural background to which they belong.

As such, throughout this essay the figure of Kathy H., protagonist of Kazuo Ishiguro's Never Let Me Go, is going to be presented as a replication of Scheherazade, adapting the trope of the storyteller to her dystopian and postcolonial context in a narration that explores the diverse roles of narratives in our lives. They serve to create a sense of community and to express one's individuality as separated; constructing and shaping our past, our dreams and hopes, blended in our identity; they are the way in which we might grasp and attempt to recover all that we have lost and, most of all, the manner in which we can communicate our experiences and survive in the memories of others. In addition, her character also incorporates another literary figure: Ulysses, the lost seafarer endeavouring to return home. 
The relationship between these three characters and their respective literary works may at first seem arbitrary. Far from it, the connections that joins them can be perceived both within the text, in its structure, themes and motifs; as much as outside of it, in the intertextual network of the Nights and Never Let Me Go. In Ishiguro's novel there is a blatant reference that would support at least a reverential attitude towards the One Thousand and One Nights and The Odyssey since these two works are mentioned in Kathy's account when she reads them to Tommy (Ishiguro 233). Concerning the intertextual connections proposed, in addition to the similarities that the Nights and The Odyssey have - especially in stories like those of Sinbad the Sailor as indicated by Irwing (71) — the Nights and Never Let Me Go can be related through another reference: George Eliot's Daniel Deronda, recurrently mentioned in the latter (Ishiguro 120-121, 124). The link between Eliot's work and the Nights has been explored by Alicia Carroll in her analysis embedded in the context of the search for an identity and the postcolonial reading of the novel (219).

In Never Let Me Go the oppression of women is nowhere to be found as female characters are diversely portrayed, exploring and performing different gender roles outside the traditional pattern of femininity (Ishiguro 170-71). In addition, there is a remarkable contrast between the proactive behaviour and resoluteness of female characters like Kathy or Ruth to the passivity of their male counterpart, Tommy (Ishiguro 240). This absence of gender or sexual oppression on the surface, we believe, would resemble the novel's apparent treatment of race as Josie Gill points out (846). As Gill continues this "postracial" reality is in fact "saturated in racialized forms of discrimination" which on the surface are barely articulated rather than hidden (2014: 846). In that sense we might say that the subjugation of women is transferred to the dimension of race and their difference (contradictorily enough) as clones. From the brief list and summary that Gill offers in the same page concerning other author's standpoints about the novel — relationship between human and animal, class struggles and the holocaust to name a few- one can see their common domain, the oppression of an objectified Other. Thus, according to these authors the novel may well be included within the group of postcolonial narratives, vision that has led Robbie B.H. Goh to term it as a "postclone-nial." (50).

Besides their upbringing, the only apparent difference that clones have with humans is a biological modification related to sexuality. Students wonder why guardians show a contradictory attitude towards sex; one of them asserts that for guardians "sex was for when you wanted babies." (Ishiguro 94). Their concern with sex puzzles the students since they are unable to have children. This connection between sexuality, reproduction and their identity as clones is reinforced by one of Kathy's classmates who believes that it is the guardians' duty to encourage sex so that their organs could function properly and they could become "good donors." (Ishiguro 94). 


\section{KATHY'S NIGHTS}

As previously stated the connection between the works mentioned is not limited to the discussed dimensions but resounds throughout Kathy's narrative, structurally and thematically. In the novel Kathy recounts the fond memories of her upbringing in Hailsham, an apparently idyllic English boarding school, alongside her dearest friends Ruth and Tommy, and the flow of their relationship from childhood to the period of donations. Beneath this seemingly candid narrative Ishiguro's novel presents a dystopian world where humans prolong their life-span thanks to the organs donated by clones who, like the three principal characters, are raised and harvested for that purpose. Around the age of eighteen clones are trained to become carers, taking care of donors until they start donating themselves and, eventually, "complete,." that is, they die. What differentiates Kathy and her schoolmates from the rest of the clones is the place and the form in which they were raised, as Hailsham constitutes a project to shelter these children from the horrors and the truth of their lives (Ishiguro 263). This exploitative situation is partially moved to the periphery of the protagonist's account as Kathy, after having lost Tommy and Ruth, focuses on the reconstruction of everyday experiences significant for her, in the fantasies created and believed in the midst of such a bleak context so as to entertain, distract and comfort herself or her audience, her donors.

As pointed out by some of Kathy's remarks, the narrative is an oral narration — perhaps a recording — as suggested by the verb "talk." (Ishiguro 2005: 45), in which Kathy addresses an interlocutor that she identifies as one of her own kind, a clone (Ishiguro 3,13). Although she does not specify who this clone might be, or if said clone is a donor or a carer, it might be fairly reasonable to think that she is presenting herself to her donor, telling him/her who she is, her story. This, in addition, serves the narrative to create an identification between the reader and clones, as Eluned Summers-Bremner argues (158), which subtly facilitates a sympathetic attitude towards them. This relationship between carer and donor gains weight when she recounts her experience with one of her donors who wanted "not just to hear about Hailsham, but to remember Hailsham, just like it had been his own childhood" (Ishiguro 5). This appropriation and reconstruction reflects one of the motivations of human narratives: the desire to merge in another's life, to belong even for a brief moment to a community.

Perhaps as a result of her appealing vital experiences, Kathy boasts that her donors tend to perform better, that is, they recover faster and also remain calm and composed even in their fourth (and final) donation (Ishiguro 3). In other words, they become more profitable to the system. Kathy is aware of and acknowledges the fact that the people in charge are pleased with her work to the point that her almost twelve years of experience as a carer might result from that (Ishiguro 3). Thus, Kathy, like the reader, might have established a connection between her excellent work and the postponement of becoming a donor (which entails her death), incurring in a post hoc fallacy.

Although as a narrator Kathy can be seen as conceited and unreliable (Ishiguro 43, 57, 129), there might be some veracity in her proud claims concerning 
her donors' performance. Their better results can be easily attributed to Kathy's artful narrative skills, weaving a story in which her memories encases other memories, avoiding a chronological structure to opt instead for an associative narration that goes back and forth; creating expectations by shifting the topic (Ishiguro 45) or by introducing elements that are left untold until much later. Examples of such design are, for instance, the narration of the Norfolk trip, interrupted in page 136 to address the issue of "possibles" and not continued until page 144 (mirroring the inclusion of metanarratives in the Nights), or how she briefly mentions the Sales in page 16 and does not explain what they are until page 42 . As Scheherazade baited the sultan by leaving her stories unfinished, so Kathy finds a way to leave her audience expectant for more.

However, this line of though finds an obstacle when taking into account the fact that Kathy knows right from the beginning that in a couple of months she is going to become a donor. Although Never Let Me Go's characters can be identified by a fierce belief in rumours, fantasies and stories to the point of delusion, perhaps it would be too much to claim that Kathy really believes that she can survive her destiny by telling her story. In truth, this finds its analogy on one of the most recurrent and pervasive fantasies of the novel: the deferrals for Hailsham couples who can prove that they are "properly in love." (Ishiguro 151). Kathy and Ruth, and eventually Tommy, in spite of its initial realist attitude, cling to this hope even when they all have grown up in Hailsham and never heard of such arrangement, but also even after one of her teachers, Miss Lucy, tells them the whole truth of their lives to stop the students' delusions about their futures (Ishiguro 80-81). Thus, even when her experiences prove the contrary Kathy might still hold on to the last hope offered by storytelling. In that sense the certitude of the outcome is not what matters but the attempt, as similarly Scheherazade is never sure if her sentence would be finally carried out in spite of her artistry.

Concerning the narration's purpose two possibilities open up depending on how it is regarded. If we consider the narrative as a recording addressed to a clone (imagine, for instance, a carer who finds in the car's glove-compartment the cassette in which his/her predecessor recorded her story), then this would enable Kathy to live in another's consciousness, overcoming the short life-span and the meaninglessness of a clone's existence each time that somebody listens this recording. In addition, as she might have found respite in storytelling from the alienation and the un-belongingness that the life of a carer entails - driving through England's deserted byroads from recovery centre to recovery centre, from donor to donorher audience might also find comfort and entertainment during their journeys. It would also serve for didactic purposes, offering answers to their existential questions, teaching them through exemplars; just as Scheherazade did with the sultan (Karahasan 64 qtd. Enderwitz 195-196). Such scenario, however, would increase the bleakness of the dystopian setting as a death sentence would also pend upon Kathy's listener, extinguishing her final hope and victory. The second possibility results from the interpretation of Kathy's account as part of her job, telling her experiences as a Hailsham student to comfort and allow her donors to partake in the life of that mythical utopia that Hailsham represents to clones. This view would be intimately 
connected with and would endow even greater significance to the structure and style that Kathy adopts to create her narrative, as the already mentioned shifts, digressions and other interruptions would be part of a conscious narrative strategy. Thanks to them she would be able to prolong the story, making her listener curious and expectant to hear it completely. This would give them something to live by, instilling in him/her the desire to live at least for another day and to recuperate from the donations faster so as to be able to receive visits; thus explaining her proud claims concerning her job. Similarly, they would remain calmer thanks to the enjoyment of the fantasies offered and to the acceptance of their fate as clones, even after learning the truth about Hailsham and other illusions, by following Kathy's example.

Moreover, Kathy is aware that as soon as her story ends, her time to become a donor will come, which links silence to death, as in Scheherazade's case. Storytelling becomes life while their silence will incarnate the acceptance of abuse. The narration not only offers her the means to denounce or solace from the hopelessness of her present, but it enables her to re-experience her life, revaluating and reconstructing the bonds that united her to her former friends and schoolmates, her only family; recovering all that she has lost in the reconnection with her home: Hailsham.

Kathy's school was a project initiated by people who, like Miss Emily, wanted to prove that "if students were reared in humane, cultivated environments." they could become "as sensitive and intelligent as human beings.." (Ishiguro 2005: 256); thus questioning to an extent the dehumanization that society imposed upon clones as part of the donation program. It is not a surprise then that for clones raised in the deplorable conditions of other centres (Ishiguro 260), Hailsham would represent a sort of utopia, a paradise, a place of infinite possibilities - like that depicted in the Nights - where all rumours and fantasies are a reality (Ishiguro 143). But for the students raised at Hailsham this mythical quality is at work as well, judging from the amount of delusional inventions that they create in relation to the school. Stories from their childhood like the Gallery, which eventually is connected by the protagonists to the rumour of deferrals, Norfolk as England's "lost corner,." where one can recover all the things s/he has lost (Ishiguro 65-66); and Hailsham's bounds and nearby forest have shaped the collective mind of the students as much as their individual understanding concerning their past, present and their future. In other words these have become archetypal in the sense that the narrative they create out of their experiences, their memory and sense of existence, is founded upon and built from them. Although the first two have a greater resonance throughout the story, the briefness and apparent simplicity of the latter offer an interesting insight on the student's collective mind. The constant haunting presence of the forest over the minds of students, especially young ones, represents to them the dangers of the outside world, binding the community together in dread. This fear is exploited in an exemplary manner, whether as a direct punishment for those who break the rules of the community (Ishiguro 50-68) or as a didactic and deterrent admonishment through the creation of ghost stories. In the latter's case Kathy recalls one in which a girl student decided to trespass the school's bounds and when she tried to return she was not allowed in by the guardians, wandering for a time outside the fences 
until she died in the outer world, resuming her vagrancy as a spirit "gazing over Hailsham, pinning to be let back in." (Ishiguro 2005: 50).

\section{MYTH AS THE LITERARY EXIT}

All these stories represent Hailsham's community politics of belonging, the strategies adopted to create a communal identity and delimit it in opposition to the identity of other groups (Yuval-Davis 204). As part of this set of strategies, narratives do not only constitute our sense of both individual and communal identity but also they give us safety and comfort in the reassurance of our belonging to a group. Even when individuals are isolated, stories enable them to be reintegrated - albeit artificially and momentarily - in that community. Clones not only endure unbelonging towards humans, within their community there is also an additional cause for that feeling: those who attended Hailsham and those who want to "remember" through narrative experience. In that sense, Scheherazade's stories are not different than Kathy's since they were the means not just to save her life but also to feel safe. Moreover, they also served to fend off the fear and pain of alienation and loneliness by partaking from one's cultural tradition, a reassurance for the individual that $s /$ he belongs to a community.

The mythologisation of Hailsham, though part of these politics of belonging, is the consequence of an essential event in Kathy's narrative, its loss. After the eventual disintegration of Kathy's group, as part of the cycle carer-donor, she learns from one of her schoolmates that Hailsham is closing (Ishiguro 207). The impact of this news is of great significance; as she reflects it was a bond that united all the students together in spite of their physical and emotional separation (Ishiguro 208). For a story that can already be understood as a narrative of exile, after this event Kathy's account acquires one of the basic themes of this type, the idea of the return; in that sense one could say that Kathy becomes the spirit of the forest's ghost story. Although she at first does not admit she actively seeks Hailsham (Ishiguro 280), she finally accept this (Ishiguro 281). In that case during her journeys throughout England she is hoping to find any landscape feature (Ishiguro 6) that would lead her, if not her old school, at least the location of its ruins. Though in a more bleak form, this personal odyssey recalls Ulysses' journey to Ithaca, his birthplace where his family awaited him. Kathy, of course, has nothing of the sort; her only family is disseminated across England, whether as solitary carers or as donors waiting for completion, while the place that she feels to belong has disappeared completely, not leaving even a last trace. Moreover, even when Kathy and Tommy finally managed to locate Miss Emily, the motherly headmaster, their meeting rather than comforting them confirms their deepest fears: that there are no deferrals for couples, that to enjoy a sheltered childhood truth was hidden from them and that Hailsham is no more (Ishiguro 260), as even its last remnant, Miss Emily's bedside cabinet, is being sold (Ishiguro 252).

Failing to physically find and return to Hailsham, Kathy eventually finds the means to get back, this time, through a narrative journey. Just as she allows 
her donors to partake of her memories and feel like a Hailsham student, so the narration of those remembrances would allow her to come back with every new retelling. As she claims after having lost Tommy and Ruth, once she becomes a donor by the end of the year she will "have Hailsham with me, safely in my head, and that'll be something no one can take away." (Ishiguro 281). In the end, being unable to become the returning hero of her personal odyssey she instead accepts the limits imposed upon her as part of her reality, embracing the powers offered by remembrance and storytelling. If not to be saved, these powers at least would allow her to be reconnected to her past; offering her a sense of belonging not just to her birthplace or social group but also to the cultural heritage that Hailsham provided for its students, perhaps the only gift left by Hailsham that does not mark them as different but reunites them with the rest of humankind. In that sense she is not different than her precursor, as Scheherazade took advantage of the stories and lore available in her cultural context, with its usual narrative patterns and cultural tropes, as the crucial element in her scheme. From these she was able to appease the anger of the sultan, healing him (Enderwitz 191) by changing his views of women from her first tales about adulterous women to her late ones in which her depiction of women becomes more positive and diverse (Blythe 2015). As Kathy's message is not likely to reach humans, her attempt is restricted to her community, reconstructing her own sense of existence by resorting to the narrative formulas offered in works like The Odyssey or the Arabian Nights in a narration that allows clones to reassert a common tradition that can be traced back to an ancient and mythical cultural heritage to which they wish to belong.

In spite of her efforts and accomplishments, Kathy ultimately fails to fulfil her role as Scheherazade since for her there is no final salvation. Despite her profitableness as a good carer, she has to complete the role imposed by society. In fact this impossibility springs from her very difference as a clone: the incapability of having children. What is usually forgotten about the Arabian Nights — probably due to its numerous versions (Ballaster 49) - is that the final pardon and the sultan's repentance is not only brought about by storytelling but by the three children that Scheherazade has with him (Nights 10: 54-55). Based on Heinz and Grotzfeld's conclusions Susanne Enderwitz argues that motherhood as the motivation of the pardon may be closer to the original sources of the Nights, underlining the relationship between "the telling of stories and giving birth (as two parallel acts of procreation)." (190-191). That Kathy would finally die as a consequence of her imposed barrenness would underline the significance of one scene in particular. Kathy narrates that, as a child, when she was hearing her Judy Bridgewater ${ }^{4}$ tape alone in her room she was being observed by Madame (Ishiguro 70-73). As she comments though the song does not talk about a mother and a baby, she was imagining herself to be holding

${ }^{4}$ That Judy Bridgewater's tape is titled Songs After Dark may be an indirect reference to the Arabian Nights and the time of the day when Scheherazade told her stories: from night until the first lights of the morning. 
her baby, singing to him/her to never let her go, a scene that made Madame cried much to the perplexity of Kathy.

\section{CONCLUSION}

Although at the end the dystopian setting prevails over all the fantasies and hopes created throughout the novel, both by characters and readers alike, Never Let $\mathrm{Me}$ Go still leaves open a space for resistance. In it memory and storytelling represent the tools through which oppressed and dehumanized individuals can reassert their own value, overcoming rootlessness in the realization that they belong to a community joined not merely by common experiences or origin but by the narratives embroidered within the group's identity. In the narratives created by them the characteristics of their social context coexist with a tradition that precedes them, influencing them by offering narrative patterns that relates them with a mythical past and through which they encode and understand both fiction and their reality. Just as Scheherazade before her, ancient stories like The Odyssey or the One Thousand and One Nights offer Kathy a device through which to understand her existence and articulate the narrative of her life and of her community, a mechanism that helps her to cope with her reality as well that allows her to teach and comfort those in her care. That in the end these narratives amount to nothing is inconsequential, what matters is the attempt to overcome the silence and alienation imposed over them as a result of society's dehumanization and objectification. In that attempt Kathy confronts her only biological difference as clone, her barrenness, by offering a depiction of her existence surprisingly human. She moves readers to sympathise with her, to see her as one of us, or rather to see us as one of them; in truth clones are the products of our social values, ideologies and cultures, they belong to us. As a protagonist, Kathy perfectly mirrors the role that Scheherazade had in her narrative: an empowered woman that though knows and, to an extent, accepts the limitations of her social context is still able to reassert her own ideas, criticising and transforming the values and views of society through a narrative creation aided by the stories legated to her. Both texts enable us to reflect on the power of narratives as a mechanism to shape both personal and communal identity, offering as part of their delight the last comfort of knowing that in the meaninglessness and finitude of existence we still belong to something beyond ourselves.

Reviews sent to author: 3 July 2017

Revised paper accepted for publication: 2 December 2017 


\section{WORKS CITED}

Ballaster, Ros. "The Sea-Born Tale: Eighteen-Century English Translations of The Thousand and One Nights and the Lure of Elemental Difference.." Scheherazade's Children: Global Encounters with the Arabian Nights. Ed. Philip F. Kennedy and Marina Warner, New York UP, 2013, pp. 27-52.

Blythe, Andrea. "Beyond Scheherazade: The Powerful Women of the One Thousand and One Arabian Nights." Nonbinary Review. Issue 6, September 2015, Web. http://www.nonbinaryreview.com/archive-2/issue-6-1001-arabian-nights/beyond-shahrazad-feministportrayals-of-women-in-the-arabian-nights/. Accessed 10 Nov. 2016.

Braga, Claudio and Conçalves, Gláucia Renate. "A Thousand and One Voices: Re-reading Scheherazade in Contemporary Arab Fiction.." Ilha do Desterro. Vol. 67, 2014, pp. 79-86.

The Book of the Thousand Nights and a Night. Trans. Richard F. Burton. The Burton Society, 1885-8. Vols. 1, 10. Burtoniana. Web. http://www.burtoniana.org/books/1885-Arabian Nights/. Accessed 27 Nov. 2016.

Carroll, Alicia. “'Arabian nights': 'Make Believe,' Exoticism, and Desire in Daniel Deronda..” Journal of English and Germanic Philology. Vol. 98, no. 2, 1999, pp. 219-238.

Coleman, Deirdre. “Post-colonialism..” In Romanticism: An Oxford Guide. Ed. Nicholas Roe, Oxford UP, 2005, pp. 237-256.

Eliade, Mircea. Myth and Reality. Trans. Willard R. Trask. New York: Harper Torchbooks, 1968.

Enderwitz, Susanne. "Shahrazâd Is One of Us: Practical Narrative, Theoretical Discussion, and Feminist Discourse..” Marvels \& Tales. Vol. 18, no. 2, 2004, pp. 187-200.

GILl, Josie. "Written on the Face: Race and Expression in Kazuo Ishiguro's Never Let Me Go.." Modern Fiction Studies. Vol. 60, no. 4, 2014, pp. 844-862.

Ghazoul, Ferial J. Nocturnal Poetics: The Arabian Nights in Comparative Context. Cairo: The American University/Cairo Press, 1996.

GoH, Robbie B.H. “The Postclone-nial in Kazuo Ishiguro's Never Let Me Go and Amitav Ghosh's The Calcutta Chromosome: Science and the Body in the Asian Diaspora.." Ariel: a review of international English literature. Vol. 41 no. 3-4, 2011, pp. 45-71.

Irwin, Robert. The Arabian Nights: A Companion. London: Allen Lane/Penguin Press, 1994.

Ishiguro, Kazuo. Never Let Me Go. London: Faber, 2005.

Jacobi Kara, Elizabeth. “'They Will Invent What They Need to Survive': Narrating Trauma in Contemporary Ethnic American Women's Fiction..” Diss. Miami U, 2009. Open Access Dissertations. Paper 229.

Khan, Jalal Uddin. "The Arabian Nights: Tales of Perennial Appeal..” The IUP Journal of English Studies. Vol. 7, no. 3, 2012, pp. 34-44.

Moblo, Pennie. "Blessed Damien of Molokài: The Critical Analysis of Contemporary Myth.." Ethnohistory, Vol. 44, no.4, 1997, pp. 691-726.

Summers-Bremner, Eluned. “Poor Creatures': Ishiguro's and Coetzee's Imaginary Animals..” Mosaic, Vol. 39, no. 4, 2006, pp. 145-160.

Yuval-Davis, Nira. "Belonging and the Politics of Belonging.." Patterns of Prejudice, Vol. 40, no. 3, 2006, pp. 197-214. 
